\title{
Temporary Performance Degradation of Photovoltaic Street Light in Kupang City, Nusa Tenggara Timur Province, Indonesia
}

\author{
Julius Tanesab ${ }^{1, *}$, Rusman Sinaga ${ }^{1}$, James Mauta ${ }^{1}$, Adrianus Amheka ${ }^{2}$, Edwin $\mathrm{Hattu}^{2}$, and \\ Ferdinan Nikson Liem ${ }^{3,4}$ \\ ${ }^{1}$ Department of Electrical Engineering, Politeknik Negeri Kupang, Jl. Adisucipto, Kupang 85258, \\ Nusa Tenggara Timur, Indonesia \\ ${ }^{2}$ Department of Mechanical Engineering, Politeknik Negeri Kupang, Jl. Adisucipto, Kupang 85258, \\ Nusa Tenggara Timur, Indonesia \\ ${ }^{3}$ Department of Civil Engineering, Politeknik Negeri Kupang, Jl. Adisucipto, Kupang, 85258, \\ Nusa Tenggara Timur Indonesia \\ ${ }^{4}$ Graduate School of Engineering Science and Technology - Construction Engineering, National \\ Yunlin University of Science and Technology, 123 University Road, Section 3, Douliu City, Yunlin \\ County, 64002, Taiwan
}

\begin{abstract}
This study investigated the effect of dust to the performance degradation of PV street lights deployed at several areas (coastal, urban, industry, and village) in Kupang city. Results showed that maximum power output $\left(\mathrm{P}_{\max }\right)$ of all modules decreased by $9 \%$ to $14 \%$. Short circuit current $\left(\mathrm{I}_{\mathrm{sc}}\right)$ was the parameter strongly affected by dust compared to open circuit voltage $\left(\mathrm{V}_{\mathrm{oc}}\right)$. Performance of the PV modules increased back to their initial conditions after cleaning. This was indicated by the increasing of $\mathrm{I}_{\mathrm{sc}}$ and $\mathrm{V}_{\mathrm{oc}}$ of the modules that leading to the escalating of their $\mathrm{P}_{\max }$ values. The worst effect of dust was exhibited by PV modules installed at coastal area. A simple analysis revealed that the module would lose $87.75 \mathrm{Wh}$ of energy $\mathrm{d}^{-1}$. This study suggested that dust derating factor applied for PV street light design in Kupang should be higher than the standard $(5 \%)$.
\end{abstract}

Keywords: PV degradation, PV performance, renewable energy, temporary degradation.

\section{Introduction}

To reduce crime rate on the street and to encourage more people to walk at night, the government of Kupang city has installed hundreds of photovoltaic (PV) streetlights since 2016. The number of the installed system is increasing and predicted to reach about one thousand units by the end of 2019. Application of the technology is based on the awareness of the government to support the utilization of environmentally friendly energy sources and reduce the grid utility load which is growing up from year to year.

\footnotetext{
*Corresponding author: julius_halan@yahoo.co.id
} 
PV module is one of the main components of the lighting system. Performance of PV panels deployed on the street are potential to decrease due to dust. Suspended dust particles in the atmosphere generated by vehicles and other surrounding activities tend to attach on the surface of the modules. As a result, transmittance of the PVs' cover glass decreased leading to the performance degradation. Energy production of the modules can be recovered by applying a cleaning procedure or by natural cleaning agents including rain.

There have been many studies about the impact of dust on PV streetlights. Al Amri et al. [1] in a work conducted in Baghdad City investigating the impact of dust on PV streetlights installed at a height of $27 \mathrm{~m}$ and an inclination of $35^{\circ}$. The results showed that performance of the modules with a capacity of $80 \mathrm{Wp}$ decreased by $26 \%$. The more the frequency of dust storm, the more the modules performance were reduced. Materials accumulating on the modules' surface were not only dust but also bird droppings, carbonbased chemicals and other materials. Solid contaminants that are difficult to be penetrated by sunlight caused hot spots on the PV s' cells. Mardikaningsih et al. [2] in a study in Solo, Indonesia compared costs between conventional and solar powered streetlights for a period of $25 \mathrm{yr}$ projection. Calculation results of net present value and benefit cost ratio revealed that the solar modules are worthy of being used as an energy source in addition to the utility for supplying streetlights. In terms of cost, PV streetlights are $97 \%$ cheaper than fossil energy sources.

Quantity of dust attached on a PV module in an area cannot be generalized for other locations. It is influenced by several environmental conditions such as temperature, humidity, rainfall, wind speed, tilt angle of the solar module, and the cover material of the solar module [3]. In other words, declining in PV performance caused by dust is not uniform for all regions. A study conducted by Adinoyi and Said [4] revealed that dust reduced the PV module power output by $50 \%$ when the panel was exposed for about six months without cleaning in the Eastern part of Saudi Arabia. A field study carried out by Kalogirou et al. [5] in Cyprus revealed that $6 \%$ to $13 \%$ reduction of power output was recorded from PV modules which had been deployed for three seasons (spring, winter and summer). Zorrilla-Casanova et al. [6] reported that daily energy loss caused by dust in southern Spain was around $4.4 \%$ over a year and it could increase to more than $20 \%$ in dry conditions. Elminir et al. [7] in their intensive experiments in Egypt found that the energy yield of PV modules decreased by around $17.4 \% \mathrm{mon}^{-1}$ for panels facing south at an angle of $45^{\circ}$.

Literature indicated that there was a need of study to determine the level of degradation caused by dust in Kupang city. This study aimed to investigate the value of power losses of the PV streetlights caused by dust in Kupang. Experiments were performed on several PV panels at some points in Kupang city which are classified as coastal, industry, village, and urban areas. The modules were left without any maintenance procedures. Results of the study are expected to provide valuable information for local governments and other stake holders to develop appropriate maintenance methods and schedules on the PV street light systems in the city.

\section{Experimental methodology}

The design of streetlights is developing very quickly. Streetlights installed in the city of Kupang have several main components such as solar modules, solar charge controllers (SCC), batteries, lamps and poles. A photograph of a PV streetlight systems in Kupang is shown in Figure. 1. Electrical connection of the components is shown in Figure 2. 


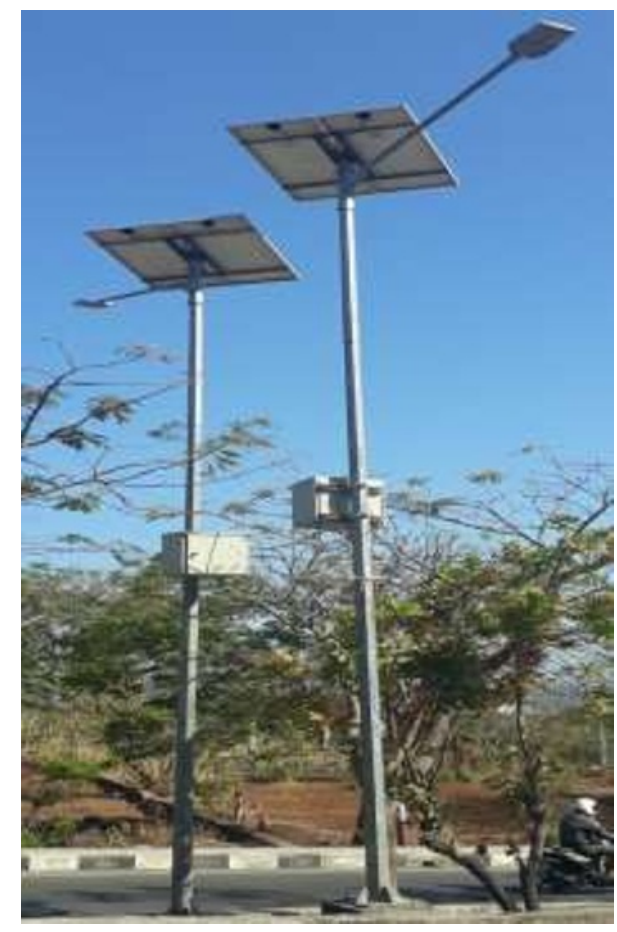

Fig. 1. PV streetlights in Kupang

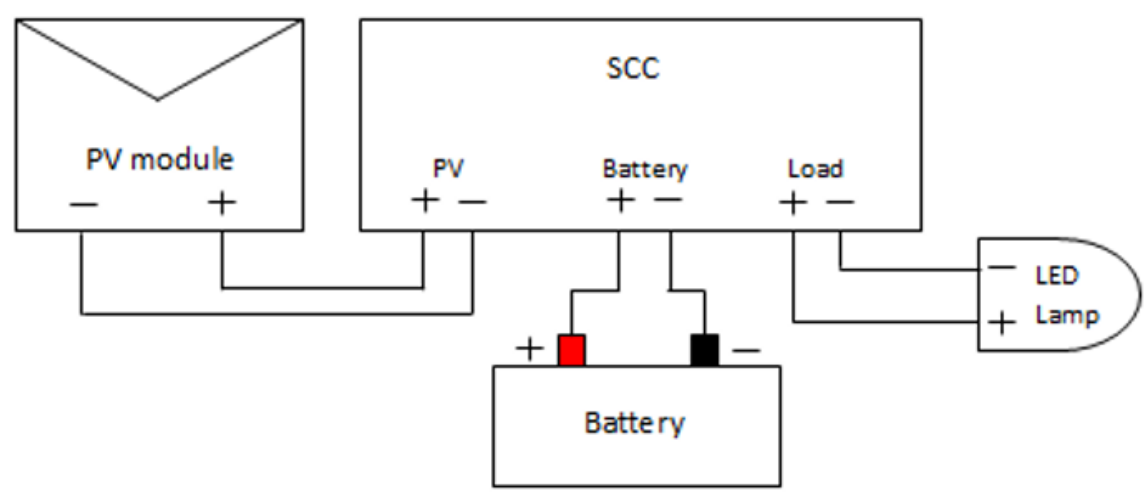

Fig. 2. Electrical circuit of PV streetlights in Kupang

The study was conducted in several places in accordance with the distribution of the PV street lights installation. These areas represented several pollution classifications namely, coastal areas, industries, urban areas, and village or rural areas. The examined modules were never cleaned by operators. Cleaning process was only carried out during the rainy season from November to March 2019. The purpose of selecting the time period of the experiment was to understand to what extend dust impact on the performance degradation of the modules during the rainy season. Four modules at each location were chosen randomly to be examined and were expected to represent the degradation levels at the area. 
To quantify the impact of dust, electrical parameters (short circuit current (Isc), open circuit voltage (Voc), and maximum power output (Pmax)) of the investigated modules were recorded in dusty condition. The modules were then cleaned and measured again as performed in clean condition. To get accurate results, measurements are made in similar condition. The modules were left to exposed to the Sun for a while before taking management in the clean conditions. The image of a PV streetlight in dusty condition is shown in Figure 3. As shown in Figure 3, shading was not only caused by dust but also by trees around the PV module area. In order to obtain more accurate results, the branches were cut before measuring the electrical parameter values.

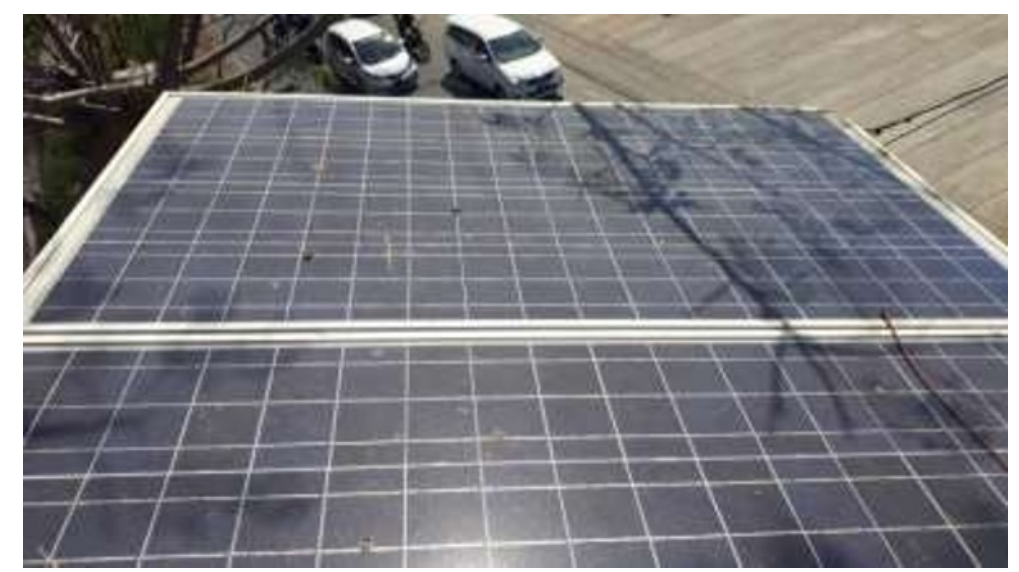

Fig. 3. Streetlight PV modules in dusty condition

The specification of the examined streetlight modules is shown in Table 1. In addition to the value of the parameters, I-V and P-V curves of the modules were traced. A Metrel $3108 \mathrm{I}-\mathrm{V}$ curve tester was deployed to take the experiments. The equipment which has uncertainty of $3 \%$ is equipped with Metrel A 3178 to enable temperature and solar irradiation measurements remotely.

Tabel 1. Electrical specification of the examined PV modules

\begin{tabular}{lr}
\hline Parameters & pc-Si module \\
\hline Maximum power (Pmax) & $100 \mathrm{~W}$ \\
Voltage @ Pmax (Vmp) & $17.3 \mathrm{~V}$ \\
Current @ Pmax (Imp) & $5.79 \mathrm{~A}$ \\
Short circuit current & $6.43 \mathrm{~A}$ \\
Open circuit voltage & $21.6 \mathrm{~V}$ \\
\hline
\end{tabular}

In addition to the high mobilization of vehicles, human activities, and environmental factors such as wind, the intensity of dust attached on the modules' surfaces are also influenced by the height of the poles. For this reason, pole height measurements were carried out as well. Streetlights in Kupang are mounted on hexagonal galvanized poles with an average height of $9 \mathrm{~m}$. The inclination angle of the examined modules was also carried out. It was found that the inclination of the modules was varied between $10^{\circ}$ and $15^{\circ}$. 


\section{Results and discussion}

To quantify the impact of dust, values of the electrical parameters of the investigated modules were recorded in dusty and clean conditions using Metrel $3108 \mathrm{I}-\mathrm{V}$ curve tester. As mentioned in experimental methodology (section 2), management were taken at four PV streetlight locations. To differentiate the modules, they were labelled in accordance with their location, for example, PV1 Urban was for PV module number 1 at urban area. Measurement results of Isc, Voc, and Pmax are depicted in Table 2 to Table 5. Examples of $\mathrm{I}-\mathrm{V}$ and $\mathrm{P}-\mathrm{V}$ curves of the module accounted highest degradation of this study are shown in Figure 4.

Table 2. The output of electrical parameters of PV modules at industry area

\begin{tabular}{|c|c|c|c|c|c|c|c|}
\hline \multirow{3}{*}{ Module } & \multicolumn{6}{|c|}{ Parameters } & \multirow{3}{*}{$\begin{array}{c}\text { Rel. diff. } \\
\text { of } P_{\max } \\
(\%)\end{array}$} \\
\hline & \multicolumn{3}{|c|}{ Dusty } & \multicolumn{3}{|c|}{ Clean } & \\
\hline & $\mathrm{V}_{\mathrm{oc}}(\mathrm{V})$ & $\mathrm{I}_{\mathrm{sc}}(\mathrm{A})$ & $\mathrm{P}_{\max }(\mathrm{W})$ & $\mathrm{V}_{\mathrm{oc}}(\mathrm{V})$ & $\mathrm{I}_{\mathrm{sc}}(\mathrm{A})$ & $\mathrm{P}_{\max }(\mathrm{W})$ & \\
\hline PV1 Industry & 19.82 & 5.40 & 82.20 & 20.06 & 5.81 & 91.16 & 9.82 \\
\hline PV2 Industry & 19.72 & 5.22 & 86.62 & 19.78 & 5.79 & 96.64 & 10.37 \\
\hline PV3 Industry & 19.80 & 5.32 & 84.36 & 19.84 & 6.63 & 94.06 & 10.30 \\
\hline PV4 Industry & 19.68 & 5.28 & 78.47 & 19.84 & 5.61 & 87.24 & 10.05 \\
\hline
\end{tabular}

Table 3. The output of electrical parameters of PV modules at urban area

\begin{tabular}{|c|c|c|c|c|c|c|c|}
\hline \multirow{3}{*}{ Module } & \multicolumn{6}{|c|}{ Parameters } & \multirow{3}{*}{$\begin{array}{c}\text { Rel. diff. } \\
\text { of } P_{\max } \\
(\%)\end{array}$} \\
\hline & \multicolumn{3}{|c|}{ Dusty } & \multicolumn{3}{|c|}{ Clean } & \\
\hline & $\mathrm{V}_{\mathrm{oc}}(\mathrm{V})$ & $\mathrm{I}_{\mathrm{sc}}(\mathrm{A})$ & $\mathrm{P}_{\max }(\mathrm{W})$ & $\mathrm{V}_{\mathrm{oc}}(\mathrm{V})$ & $\mathrm{I}_{\mathrm{sc}}(\mathrm{A})$ & $\mathrm{P}_{\max }(\mathrm{W})$ & \\
\hline PV1 Urban & 18.01 & 5.15 & 84.89 & 18.20 & 5.82 & 96.95 & 12.44 \\
\hline PV2 Urban & 18.19 & 5.10 & 81.92 & 18.23 & 5.75 & 93.12 & 12.02 \\
\hline PV3 Urban & 19.81 & 5.66 & 86.15 & 19.86 & 6.35 & 99.64 & 13.53 \\
\hline PV4 Urban & 18.48 & 4.97 & 80.66 & 18.51 & 5.69 & 92.05 & 12.37 \\
\hline
\end{tabular}

Table 4. The output of electrical parameters of PV modules at coastal area

\begin{tabular}{|c|c|c|c|c|c|c|c|}
\hline \multirow{3}{*}{ Module } & \multicolumn{6}{|c|}{ Parameters } & \multirow{3}{*}{$\begin{array}{c}\text { Rel. diff. } \\
\text { of } P_{\max } \\
(\%)\end{array}$} \\
\hline & \multicolumn{3}{|c|}{ Dusty } & \multicolumn{3}{|c|}{ Clean } & \\
\hline & $\mathrm{V}_{\mathrm{oc}}(\mathrm{V})$ & $\mathrm{I}_{\mathrm{sc}}(\mathrm{A})$ & $\mathrm{P}_{\max }(\mathrm{W})$ & $\mathrm{V}_{\mathrm{oc}}(\mathrm{V})$ & $\mathrm{I}_{\mathrm{sc}}(\mathrm{A})$ & $\mathrm{P}_{\max }(\mathrm{W})$ & \\
\hline PV1 Coastal & 19.70 & 5.72 & 83.30 & 20.04 & 6.42 & 96.80 & 13.94 \\
\hline PV2 Coastal & 20.85 & 5.53 & 85.50 & 21.05 & 6.15 & 98.34 & 13.09 \\
\hline PV3 Coastal & 19.30 & 5.41 & 80.88 & 19.60 & 6.20 & 91.16 & 11.27 \\
\hline PV4 Coastal & 19.75 & 5.61 & 83.61 & 19.80 & 6.38 & 96.32 & 13.18 \\
\hline
\end{tabular}

Table 5. The output of electrical parameters of PV modules at village area

\begin{tabular}{|c|c|c|c|c|c|c|c|}
\hline \multirow{3}{*}{ Module } & \multicolumn{6}{|c|}{ Parameters } & \multirow{3}{*}{$\begin{array}{l}\text { Rel. diff. } \\
\text { of } P_{\max } \\
(\%)\end{array}$} \\
\hline & \multicolumn{3}{|c|}{ Dusty } & \multicolumn{3}{|c|}{ Clean } & \\
\hline & $\mathrm{V}_{\text {oc }}(\mathrm{V})$ & $\mathrm{I}_{\mathrm{sc}}(\mathrm{A})$ & $\mathrm{P}_{\max }(\mathrm{W})$ & $\mathrm{V}_{\mathrm{oc}}(\mathrm{V})$ & $\mathrm{I}_{\mathrm{sc}}(\mathrm{A})$ & $\mathrm{P}_{\max }(\mathrm{W})$ & \\
\hline PV1 Village & 20.02 & 5.30 & 88.94 & 20.04 & 5.80 & 97.89 & 9.14 \\
\hline PV2 Village & 19.70 & 5.32 & 79.29 & 19.74 & 5.72 & 87.26 & 9.13 \\
\hline PV3 Village & 18.41 & 4.98 & 81.83 & 18.48 & 5.62 & 90.20 & 9.28 \\
\hline PV4 Village & 19.43 & 5.48 & 86.28 & 19.72 & 5.94 & 95.61 & 9.75 \\
\hline
\end{tabular}

Test results show that power output $\left(\mathrm{P}_{\max }\right)$ of all modules decreased by $9 \%$ to $14 \%$ due to dust. Short circuit current $\left(\mathrm{I}_{\mathrm{sc}}\right)$ is the parameter that was strongly affected by dust compared to open circuit voltage $\left(\mathrm{V}_{\mathrm{oc}}\right)$. Performance of the PV modules increased back to their initial conditions after cleaning with a procedure as described in the methodology section. This is indicated by the greater values of $\mathrm{I}_{\mathrm{sc}}$ and $\mathrm{V}_{\mathrm{oc}}$ of the modules in clean condition that leading to the increasing of their $\mathrm{P}_{\max }$ values. 


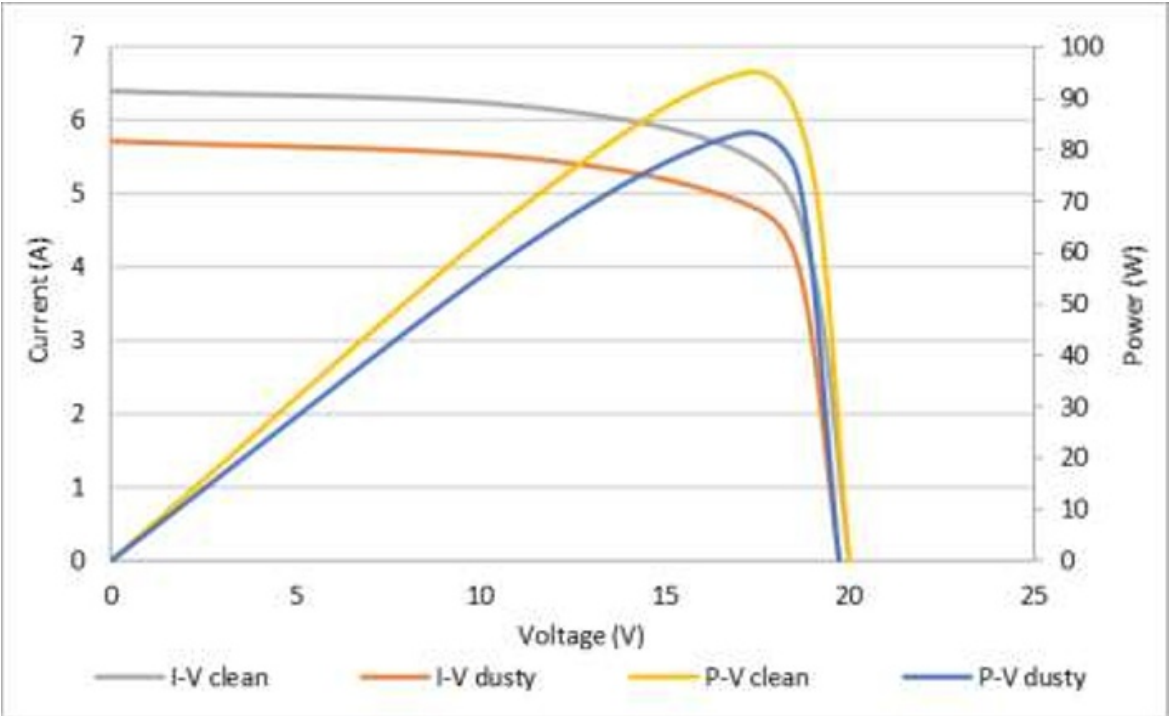

Fig. 4. I-V and P-V curves of the most affected PV module in dusty and clean conditions

The worst effect of dust was exhibited by PV modules installed at coastal area which accounted an average of $14 \%$. One of the dominant factors contributing to the degradation is the amount of dust attached to the PV modules' surface. In addition to the quantity, the impact of dust to the performance of PV modules is also influenced by its morphology including size and shape. Fine and smooth dust shared greater effect to block sunlight compared to the large and porous ones $[8,9]$. Based on this explanation, it can be predicted that the amount of dust attached on the surface of the PV modules in the coastal area is higher than ones at the other regions. Another possibility is that dust in the coastal area is finer and smoother compared to that in other areas. However, further research is still needed to analyse the amount of dust and its morphology.

From the results of this study, a simple analysis can also be performed to determine energy losses caused by dust. Referring to the works of Tanesab et al. [10,11] and considering that Kupang city receives an annual average of 6.3 peak sun $\mathrm{h} \mathrm{d}^{-1}$ [12], 87.75 Wh $(13.5 \mathrm{~W} \times 6.3 \mathrm{~h})$ of energy would be loos by the worst affected module installed at the coastal area every day. This situation will certainly continue to get higher until the dust on the modules' surface have been washed away during rainy season (8 mo ahead). Therefore, further study is also needed to analyse the economic impact of dust in order to predict the best time for cleaning the modules. Tanesab et al. [13, 14] and Cristaldi et al. [15] suggest that a cleaning procedure will be effective when economic losses caused by dust are greater than maintenance costs.

Most of standards including Australian/New Zealand Standards [16] recommends that $5 \%$ of dust derating factor should be taken into account for a PV design. But the results of this study suggested that a higher value of dust derating factor should be applied for PV design in Kupang. In addition, a comprehensive study of the impact of dust need to be conducted before constructing a PV system in an area. 


\section{Conclusion}

This study investigated the effect of dust to the performance degradation of PV streetlights deployed at several areas (coastal, urban, industry, and village) in Kupang. Results showed that maximum power output $\left(\mathrm{P}_{\max }\right)$ of all modules decreased by $9 \%$ to $14 \%$ due to dust. Short circuit current ( $\mathrm{Isc}_{\mathrm{sc}}$ ) was the parameter strongly affected by dust compared to open circuit voltage $\left(\mathrm{V}_{\mathrm{oc}}\right)$. Performance of the PV modules increased back to their initial conditions after cleaning. This is indicated by the greater values of $I_{s c}$ and $V_{o c}$ of the modules in clean condition that leading to the increasing of their Pmax values. The worst effect of dust was exhibited by PV modules installed at coastal area. A simple analysis revealed that the module would lose $87.75 \mathrm{Wh}$ of energy every day. Therefore, further study is needed to analyse the economic impact of dust in order to predict the best time for cleaning the modules. This study suggested that a higher value of dust derating factor (> $5 \%$ ) should be applied for PV design in Kupang. In addition, a comprehensive study of the impact of dust need to be conducted before constructing a PV system in an area.

The authors would like to acknowledge financial aid from KEMENRISTEKDIKTI Indonesia through Basic Research Grant (Hibah Penelitian Dasar) in 2019 with a contract number: 142/SP2HL/LT/DRPM/2019.

\section{References}

1. A.S. Al-Ammri, A. Ghazi, F. Mustafa, Dust effects on the performance of PV streetlight in Baghdad city, 2013 International Renewable and Sustainable Energy Conference (IRSEC), (Ouarzazate, Mexico, 2013)

https://ieeexplore.ieee.org/document/6529687

2. I.S. Mardikaningsih, W. Sutopo, M. Hisjam, R. Zakaria, Techno-economic feasibility analysis of a public streetlight with solar cell power, International MultiConference of Engineers and Computer Scientists, (Hong Kong, 2016).

http://www.iaeng.org/publication/IMECS2016/IMECS2016_pp769-773.pdf

3. T. Sarver, A. Al-Qaraghuli, L. L. Kazmerski, Renewable and Sustainable Energy Reviews, 22:698-733(2013)

https://www.sciencedirect.com/science/article/abs/pii/S136403211300021X

4. M.J. Adinoyi, S.A.M. Said, Renewable Energy, 60:633-636(2013)

https://www.sciencedirect.com/science/article/abs/pii/S0960148113003078

5. S.A. Kalogirou, R. Agathokleous, G. Panayiotou, Energy, 51:439-446(2013). https://www.sciencedirect.com/science/article/abs/pii/S0360544212009309।

6. J.Z. Casanova, M. Piliougine, J. Carretero, P. Bernaola, P. Carpena, L.M. Lopez, et al., Analysis of dust losses in photovoltaic modules, Photovoltaic Technology - Word Renewable Energy Congress, (Linkoping, Sweden, 2011), p. 2985-2992. https://www.irishellas.com/files/Analysis-of-dust-losses-in-photovoltaicmodules_2011.pdf

7. H.K. Elminir, A.E. Ghitas, R.H. Hamid, F. El-Hussainy, M.M. Beheary, K.M. Abdel-Moneim, Energy Conversion and Management, 47,18-19:3192-3203(2006). https://www.sciencedirect.com/science/article/pii/S0196890406000562

8. J. Tanesab, D. Parlevliet, J. Whale, T. Urmee, Sustainable Energy Technologies and Assessments, 31:347-354(2019) .https://www.sciencedirect.com/science/article/abs/pii/S2213138816302302 
9. J. Tanesab, M.D. Letik, A. Tino, Y.S. Peli, Experimental study of dust impact on power output degradation of various photovoltaic technologies deployed in West Timor, Indonesia, IOP Conference Series: Earth and Environmental Science, (Shanghai, China, 2018), p. 1-8.

https://iopscience.iop.org/article/10.1088/1755-1315/188/1/012038

10. J. Tanesab, D. Parlevliet, J. Whale, T. Urmee, T. Pryor, Solar Energy, 120: 147-157(2015).

https://www.sciencedirect.com/science/article/abs/pii/S0038092X15003837

11. J. Tanesab, D. Parlevliet, J. Whale, T. Urmee, Renewable Energy, 111:

105-115(2017).

https://www.sciencedirect.com/science/article/abs/pii/S0960148117302823

12. NASA, NASA Surface meteorology and Solar Energy - Location [Online] from https://power.larc.nasa.gov/ (Accessed on 1 December, 2015.)

13. J. Tanesab, D. Parlevliet, J. Whale, T. Urmee. Renewable Energy, 120:401412(2018)

https://www.sciencedirect.com/science/article/abs/pii/S0960148117312806

14. J. Tanesab, D. Parlevliet, J. Whale, T. Urmee, Energy Procedia, 100:65-68(2016) https://www.sciencedirect.com/science/article/pii/S1876610216311158

15. L. Cristaldi, M. Faifer, M. Rossi, M. Catelani, L. Ciani, E. Dovere, et al., Economical evaluation of PV system losses due to the dust and pollution. Instrumentation and Measurement Technology Conference (I2MTC), (Graz, Austria, 2012), p. 614-618. https://ieeexplore.ieee.org/abstract/document/6229521/

16. Australian/New Zealand Standard Committee. Stand-alone power systems. Part 2: System design. New Zealand: Standards Australia Limited (2010).

https://archive.org/details/as-nzs.4509.2.2010/page/n11/mode/2up 